\title{
Local Groundnut Genotypes Screened against Tikka Disease of Groundnut
}

\author{
J.M. Parbat ${ }^{1}$, M.Y. Nadare ${ }^{1}$, K.N. Uikey ${ }^{2}$ and H.K. Wankhede ${ }^{3}$ \\ ${ }^{1}$ Plant Pathology Section, College of Agriculture, Nagpur, India \\ ${ }^{2}$ Genetics and Plant Breeding Section, College of Agriculture, Nagpur, India \\ ${ }^{3}$ Entomology Section, PGI M.P.K.V, Rahuri, India \\ *Corresponding author
}

\begin{abstract}
A B S T R A C T
An experiment was conducted at College of Agriculture, Nagpur to screen forty different groundnut genotypes against tikka disease of groundnut during kharif, 2016-17 in

Keywords

Early leaf spot, Late leaf spot,

Groundnut genotypes

\section{Article Info}

Accepted: 20 July 2018 Available Online: 10 August 2018 randomized block design with three replications. Biochemical constituents of phenol, total sugar and chlorophyll at 45-50DAS (flowering stage) and 90DAS (pod development stage) were estimated from leaves of healthy and diseased samples. Forty genotypes of groundnut were screened for tikka disease under field condition. None of the genotypes were found to be immune to early leaf spot. Two entries (ACNGV-25, ACGGV-30) were highly resistant, seven entries (Kopergaon-3, 3, 10, 14, ACGGV-27, 36, 38) were resistant, fourteen entries (ACNGV-2, 5, 8, 9, 11, 13, 18, 26, ACGGV-28, 29, 31, 33, 34, 35) were moderately resistant, thirteen entries (ACNGV-1, 4, 6, 7, 12, 15, 17, 19, 21, 22, 23, 24, ACGGV-32 were susceptible) and four entries (ACNGV-16, 20, ACGGV-37, TAG-24) were highly susceptible to the early leaf spot. Similarly none of the genotypes were found to be immune and highly resistant to late leaf spot disease. One entry (Kopergaon-3) was resistant, one entry (ACGGV-30) was moderately resistant, thirty six entries (ACNGV-1, $2,3,4,5,6,7,8,9,10,11,12,13,14,15,18,19,20,21,22,23,24,25,26$, ACGGV -27, $28,29,31,32,33,34,35,36,37,38$, TAG-24) were susceptible and two entries (ACNGV-16, 17) were highly susceptible to the late leaf spot.
\end{abstract}

\section{Introduction}

Groundnut (Arachis hypogaea L.) is one of the principle oilseed crops of the world. Groundnut is unique among all the leguminous crops, designated as "wonder legume", commonly called as the poor man's nut and belongs to leguminous family. The botanical name for groundnut, Arachis meaning a legume and hypogaea meaning below ground. It is an important protein supplements in cattle and poultry rations. It is also consumed as confectionary product. The cake can be used for manufacturing artificial fiber. The haulms (plant stalks) are fed (green, dried or silage) to livestock. Groundnut shell is used as fuel for manufacturing coarse boards, cork substitutes etc. The oil content of the seed varies from $44-55 \%$. Groundnut oil is used for cooking; kernels are eaten raw, roasted and salted or sweetened. They are rich in protein (22-32\%), carbohydrates (20\%) and 
contain vitamins $\mathrm{A}, \mathrm{E}, \mathrm{K}$ and $\mathrm{B}$ groups. It is also one of the richest sources of $B_{1}$. Groundnut cake, formed after the oil extraction is a highly proteinacious animal feed.

Groundnut crop often suffers from many fungal, bacterial, viral, phytoplasma, nematode diseases and pests. The major biotic factors affecting groundnut yield and quality in India are foliar fungal diseases, stem rot, collar rot, root rot, rust and seedling rots etc. Early (Cercospora arachidicola Hori.) and late leaf spots (Phaeoisariopsis personata Berk. and Curt.) are the most widely distributed and economically important foliar diseases of groundnut causing severe damage to the crop (Subrahmanyam et al., 1985). Each disease alone is capable of causing substantial yield loss but when they occur together losses are further increased. For instance, rust and late leaf spot together can cause up to 70 per cent yield loss also have an adverse influence on seed quality and grade characteristics, deteriorate the quality of plant biomass and thus render the fodder quality production in groundnut growing in Vidarbha region (Maharashtra). Early and late leaf spot commonly called as "Tikka disease".

Loss of production from the combined effect of the both leaf spot can ranges from 10-50 per cent depending on the time of appearance and weather. These diseases damage the plant by reducing the leaf area available for photosynthesis and stimulating the leaflet abscission leading to heavy defoliation (Subrahmanyam et al., 1985). Use of disease resistant cultivators is one of the best means of reducing crop losses from leaf spot disease. Considering the importance of disease, this study was undertaken with the objectives to screen the groundnut germplasm against tikka disease and to study biochemical constituents of germplasm against tikka disease.

\section{Materials and Methods}

A field experiment was conducted at Plant pathology farm, College of Agriculture, Nagpur during kharif season of 2016-17. The experiment was laid out in randomized block design. All standard and recommended packages of practices such as tillage, manuring, sowing, fertilizer application, weeding and pest control were followed for cultivation of crop as when required. The disease intensity was recorded from five plants of each germplasm. Six leaves of each plant ( 2 top leaves, 2 middle leaves, 2 bottom leaves) were selected for measurement of disease intensity on the basis of relative percentage of leaf area covered by disease per cent disease intensity (PDI) was calculated by formula given by Wheeler (1969).

PDI $=\frac{\text { Sum of individual disease rating }}{\text { No. of leaves observe } X \text { Maximum disease grade }} \times 100$

Screening of groundnut germplasm against tikka disease resistance was done based on disease scoring scale given by Mayee and Datar (1988) (Table 1).

\section{Results and Discussion}

\section{Symptoms of tikka disease of groundnut}

The symptoms produced by two pathogens viz., Cercospora arachidicola and Phaeoisariopsis personata were different in size, shape and colour of lesions. Phaeoisariopsis personata spots at maturity were black on both the surface of leaf with lower surface attaining different shades. The size of spots varied from 1.5 to $3.5 \mathrm{~mm}$. Halos around mature spots attain a golden yellow. Cercospora arachidicola were dark brown on leaf surface. The spot varied in size from 3 to $5 \mathrm{~mm}$ from round to irregular in size, when they turned yellow to golden and generally lighter than Phaeoisariopsis personata. 
Similar to this observations Ramakrishna and Appa Rao (1968) reported that apart from the time of appearance, the symptoms produced by two pathogens viz. Cercospora arachidicola and Cercospora personata different in size, shape and colour of lesions. The symptoms of Phaeoisariopsis personata which appeared on the upper surface of older leaves were dark brown to black spots measuring 1 to $6 \mathrm{~mm}$ in diameter almost circular in out and with an distinct pale yellow margin. Cercospora arachidicola produced reddish brown more or less circular to irregular lesions measuring about 1 to 10 $\mathrm{mm}$ in diameter and surrounded by a narrow bright yellow halo. These observations correlated with findings of Mayee and Datar (1988), who reported that the symptoms of Cercospora personata which appeared on the upper surface of older leaves were dark brown to black spots.

\section{Screening of genotypes}

Thirty eight genotypes and two check varieties were screened under natural field condition against early and late leaf spot disease. Out of forty entries tested (Table 2) none of the genotypes were found to be immune to this disease. Two entries (ACNGV-25, ACGGV-30) showed highly resistant, seven showed resistant (Kopergaon3, 3, 10, 14, ACGGV-27, 36, 38), fourteen showed moderately resistant (ACNGV$2,5,8,9,11,13,18,26, \quad$ ACGGV-28, 29, $31,33,34,35)$, thirteen showed susceptible (ACNGV-1, 4, 6, 7, 12, 15, 17, 19, 21, 22, 23, 24, ACGGV-32) and four showed highly susceptible (ACNGV-16,20, ACGGV-37, TAG-24) in reaction to the early leaf spot.

The same forty entries tested against late leaf spot (Table 3) and found that none of the genotypes were found to be immune and highly resistant to this disease. One entry (Kopergao-3) was resistant and one moderately resistant (ACGGV-30), thirty six were susceptible (ACNGV- 1, 2, 3, 4, 5, 6, 7, $8,9,10,11,12,13,14,15,18,19,20,21,22$, $23,24,25,26$, ACGGV-27, 28, 29, 31, 32, $33,34,35,36,37,38$, TAG-24) and two were highly susceptible (ACNGV-16, 17) in reaction to the late leaf spot.

The data presented in Table 4 revealed that susceptible genotypes showed maximum per cent disease intensity as compared to resistant genotypes. Among 40 genotypes of groundnut ACNGV-16 (9.25\%), ACNGV-20 (10.74\%) showed maximum, ACGGV-30 (2.59\%), ACNGV-25 (2.96\%) showed minimum per cent disease intensity to early leaf spot at flowering stage and ACNGV-16 (41.11\%), ACNGV-17 (43.33\%) showed maximum, Kopergaon-3 (18.89\%), ACGGV-30 $(21.85 \%)$ showed minimum per cent disease intensity to late leaf spot at pod development stage.

Similar to this result Sheela (2008) screened the 48 groundnut entries and found that INS1-2006-5 and INS-1-2005-16 were found to be resistant to rust (grade 1.3 and 1.0 respectively) and late leaf spot (grade 3.0 and 2.0 respectively). Other two entries viz., INS1-2006-10 and AIS-2006-11 were found to be resistant to late leaf spot disease alone (grade 2.6 and 2.0 respectively).The susceptible variety CO-2 recorded grade 8.3 for rust and 8.8 for late leaf spot diseases. Mane Pushpa (2012) tested total 14 groundnut cultivars and 3 check varieties against tikka disease under natural field conditions. The per cent disease intensity was worked out for each variety, based on visual observations of 5 plants plot $^{-1}$ replication $^{-1}$. Among the cultivars AK-208-14 showed moderately susceptible reaction whereas all other cultivars showed susceptible reaction to tikka disease. The check variety TAG-24 showed moderately susceptible reaction against tikka diseases among three check varieties. 
Table.1 Disease scoring scale

\begin{tabular}{|l|l|l|}
\hline $\mathbf{0}$ & Immune & No symptoms \\
\hline $\mathbf{1}$ & Highly Resistant & Few small necrotic spots covering 1\% or less of leaf area. \\
\hline $\mathbf{3}$ & Resistant & Few small necrotic spots covering 1-5\% of leaf area. \\
\hline $\mathbf{5}$ & Moderately Resistant & Spots coalescing enlarging 6-20\% of leaf area. \\
\hline $\mathbf{7}$ & Susceptible & Spot enlarging, coalescing to cover 21-50\% of the compound leaf area. \\
\hline $\mathbf{9}$ & Highly Susceptible & Spot enlarging, coalescing to cover 51\% or more of the leaf area. \\
\hline
\end{tabular}

Table.2 Reaction of groundnut genotypes against early leaf spot disease

\begin{tabular}{|c|l|c|l|}
\hline Scale & Category & No. of genotypes & Genotypes \\
\hline 0 & Immune (I) & 0 & Nil \\
\hline 1 & Highly Resistant (HR) & 2 & ACNGV-25, ACGGV-30 \\
\hline 3 & Resistant (R) & 7 & $\begin{array}{l}\text { ACNGV-3, 10, 14, and ACGGV-27, 36, } \\
38 .\end{array}$ \\
\hline & & Kopergaon-3 \\
\hline 5 & $\begin{array}{l}\text { Moderately Resistant } \\
\text { (MR) }\end{array}$ & 14 & $\begin{array}{l}\text { ACNGV-2, 5, 8, 9, 11, 13, 18, 26, } \\
\text { ACGGV-28, 29, 31, 33, 34, 35. }\end{array}$ \\
\hline 7 & Susceptible (S) & 13 & $\begin{array}{l}\text { ACNGV-1, 4, 6, 7, 12, 15, 17, 19, 21, 22, } \\
\text { 23, 24, }\end{array}$ \\
\hline & & ACGGV-32, \\
\hline 9 & $\begin{array}{l}\text { Highly Susceptible } \\
\text { (HS) }\end{array}$ & 4 & ACNGV-16, 20, ACGGV-37, TAG-24 \\
\hline
\end{tabular}

Table.3 Reaction of groundnut genotypes against late leaf spot disease

\begin{tabular}{|c|c|c|c|}
\hline Scale & Category & $\begin{array}{c}\text { No. of } \\
\text { genotypes }\end{array}$ & Genotypes \\
\hline 0 & Immune (I) & 0 & Nil \\
\hline 1 & Highly Resistant (HR) & 0 & Nil \\
\hline 3 & Resistant (R) & 1 & Kopergao-3 \\
\hline 5 & Moderately Resistant (MR) & 1 & ACGGV-30 \\
\hline 7 & Susceptible (S) & 36 & $\begin{array}{l}\text { ACNGV-1,2,3,4,5,6,7,8,9,10,11, } \\
12,13,14,15,18,19,20,21,22,23,24,25,26 \\
\text { ACGGV-27, 28, 29, 31, 32, 33, 34, 35, 36,37, } \\
38 \text { and TAG-24. }\end{array}$ \\
\hline 9 & Highly Susceptible (HS) & 2 & ACNGV-16, 17 \\
\hline
\end{tabular}


Table.4 Per cent disease intensity of early and late leaf spot on groundnut genotypes

\begin{tabular}{|c|c|c|c|c|}
\hline \multirow[t]{2}{*}{ Genotypes } & \multicolumn{2}{|c|}{ Disease reaction } & \multicolumn{2}{|c|}{ PDI } \\
\hline & ELS & LLS & ELS & LLS \\
\hline ACNGV-1 & $\mathrm{S}$ & $\mathrm{S}$ & $8.51(16.96)$ & $37.40(37.70)$ \\
\hline ACNGV-2 & MR & S & $5.92(14.08)$ & $35.92(36.82)$ \\
\hline ACNGV-3 & $\mathrm{R}$ & $\mathrm{S}$ & $3.33(10.51)$ & $32.22(34.58)$ \\
\hline ACNGV-4 & $\mathrm{S}$ & $\mathrm{S}$ & $8.14(16.57)$ & $35.92(36.82)$ \\
\hline ACNGV-5 & MR & $\mathrm{S}$ & $5.55(13.62)$ & $34.44(35.93)$ \\
\hline ACNGV-6 & $\mathrm{S}$ & $S$ & $7.03(15.37)$ & $33.7(35.48)$ \\
\hline ACNGV-7 & $\mathrm{S}$ & S & $7.4(15.78)$ & $40.37(39.44)$ \\
\hline ACNGV-8 & MR & $\mathrm{S}$ & $5.48(13.53)$ & $35.92(36.82)$ \\
\hline ACNGV-9 & MR & $\mathrm{S}$ & $6.29(14.52)$ & $31.48(34.12)$ \\
\hline ACNGV-10 & $\mathrm{R}$ & $S$ & $4.07(11.63)$ & $36.66(37.26)$ \\
\hline ACNGV-11 & MR & $\mathrm{S}$ & $5.55(13.62)$ & $34.44(35.93)$ \\
\hline ACNGV-12 & $\mathrm{S}$ & $\mathrm{S}$ & $7.03(15.37)$ & $33.7(35.48)$ \\
\hline ACNGV-13 & MR & $\mathrm{S}$ & $5.92(14.08)$ & $33.7(35.48)$ \\
\hline ACNGV-14 & $\mathrm{R}$ & $\mathrm{S}$ & $4.81(12.66)$ & $33.7(35.48)$ \\
\hline ACNGV-15 & $\mathrm{S}$ & $\mathrm{S}$ & $8.51(16.96)$ & $37.4(37.70)$ \\
\hline ACNGV-16 & HS & HS & $9.25(17.70)$ & $41.11(39.87)$ \\
\hline ACNGV-17 & $\mathrm{S}$ & HS & $7.77(16.18)$ & $43.33(41.16)$ \\
\hline ACNGV-18 & MR & $\mathrm{S}$ & $6.29(14.52)$ & $36.66(37.26)$ \\
\hline ACNGV-19 & $\mathrm{S}$ & $\mathrm{S}$ & $7.77(16.18)$ & $36.66(37.26)$ \\
\hline ACNGV-20 & HS & S & $10.74(19.13)$ & $38.14(38.13)$ \\
\hline ACNGV-21 & $\mathrm{S}$ & $\mathrm{S}$ & $7.03(15.37)$ & $35.18(36.37)$ \\
\hline ACNGV-22 & S & $\mathrm{S}$ & 7.77 (16.18) & $34.44(35.93)$ \\
\hline ACNGV-23 & $S$ & $S$ & $8.14(16.58)$ & $37.4(37.70)$ \\
\hline ACNGV-24 & $\mathrm{S}$ & S & $8.51(16.96)$ & $36.66(37.26)$ \\
\hline ACNGV-25 & HR & S & $2.96(9.90)$ & $36.66(37.26)$ \\
\hline ACNGV-26 & MR & $\mathrm{S}$ & $5.18(13.15)$ & $31.48(34.12)$ \\
\hline ACGGV-27 & $\mathrm{R}$ & $\mathrm{S}$ & $4.44(12.16)$ & $35.92(36.82)$ \\
\hline ACGGV-28 & MR & $\mathrm{S}$ & $5.18(13.15)$ & $35.18(36.37)$ \\
\hline ACGGV-29 & MR & $\mathrm{S}$ & $5.92(14.08)$ & $35.92(36.82)$ \\
\hline ACGGV-30 & HR & MR & $2.59(9.26)$ & $21.85(27.86)$ \\
\hline ACGGV-31 & MR & $\mathrm{S}$ & $5.18(13.15)$ & $32.95(35.03)$ \\
\hline ACGGV-32 & $\mathrm{S}$ & $\mathrm{S}$ & $7.77(16.18)$ & $37.4(37.70)$ \\
\hline ACGGV-33 & MR & $\mathrm{S}$ & $6.29(14.52)$ & $37.4(37.70)$ \\
\hline ACGGV-34 & MR & S & $5.55(13.62)$ & $36.66(37.26)$ \\
\hline ACGGV-35 & MR & $\mathrm{S}$ & $5.92(14.08)$ & $32.96(35.03)$ \\
\hline ACGGV-36 & $\mathrm{R}$ & $\mathrm{S}$ & 4.07 (11.63) & $34.44(35.93)$ \\
\hline ACGGV-37 & HS & S & $9.25(17.70)$ & $32.96(35.03)$ \\
\hline ACGGV-38 & $\mathrm{R}$ & $\mathrm{S}$ & 3.7 (11.09) & $38.83(38.54)$ \\
\hline TAG-24 & HS & $\mathrm{S}$ & $10(18.43)$ & $33.7(35.48)$ \\
\hline Kopergaon-3 & $\mathrm{R}$ & $\mathrm{R}$ & $4.07(11.63)$ & $18.89(25.76)$ \\
\hline $\mathrm{SE} \mathrm{m} \pm$ & & & 0.70 & 0.50 \\
\hline $\mathrm{CD}(0.05)$ & & & 2.02 & 1.51 \\
\hline
\end{tabular}

\section{References}


Bhaskar, A. V. and A. M. Parakhia, 2010. Biochemical changes in resistant and susceptible varieties of peanut (Arachis hypogaea) in relation to early and late leaf spot disease. Indian J. Oilseeds Res. 27 (2): 195-196.

Benedict, S.R. 1907. The detection and estimation of reducing sugars. J. Biol. Chem. 3:101-117.

Gupta, S. K., P. P. Gupta, C. D. Kaushik and G. S. Saharan, 1987. Biochemical changes in leaf surface extract and total chlorophyll content of sesame in relation to Alternaria leaf spot disease (Alternaria sesami). Indian J. Mycol.
Plant. Path. 17 (2): 165-168.

Mayee, C. D., and V. V Datar, 1988. Phytopathometry technical bulletin-1, published by Marathawada Agriculture University, Parbhani. pp.90.

Ramakrishna, T.S. and A. Appa Rao, 1968. Studies on the tikka disease of groundnut. Indian Phytopath. 21: 31-36.

Subrahmanyam, P., V. K. Mehan, D. J. Nevill, and D. McDonald, 1980. Research on fungal diseases of groundnut at ICRISAT pp. 193-198.

Wheeler, B.E.J, 1969. An introduction to plant diseases. John Wiley and Sons Ltd., London.

\section{How to cite this article:}

Parbat, J.M., M.Y. Nadare, K.N. Uikey and Wankhede, H.K. 2018. Local Groundnut Genotypes Screened against Tikka Disease of Groundnut. Int.J.Curr.Microbiol.App.Sci. 7(08): 3645-3650. doi: https://doi.org/10.20546/ijcmas.2018.708.369 